\title{
Reversibility of Soil Productivity Decline with Organic Matter of Differing Quality Along a Degradation Gradient
}

\author{
Joseph M. Kimetu, ${ }^{1}$ Johannes Lehmann, ${ }^{1 *}$ Solomon O. Ngoze, ${ }^{2}$ Daniel \\ N. Mugendi, ${ }^{3}$ James M. Kinyangi, ${ }^{1}$ Susan Riha, ${ }^{2}$ Lou Verchot, ${ }^{4}$ John \\ W. Recha, ${ }^{1}$ and Alice N. Pell ${ }^{5}$
}

\begin{abstract}
${ }^{1}$ Department of Crop and Soil Sciences, Cornell University, Ithaca, New York 14853, USA; ${ }^{2}$ Department of Earth and Atmospheric Sciences, Cornell University, Ithaca, New York 14853, USA; ${ }^{3}$ School of Environmental Studies and Human Sciences, Kenyatta University, P.O. Box 43844-00100, Nairobi, Kenya; ${ }^{4}$ World Agroforestry Centre (ICRAF), P.O. Box 30677-00100, United Nations Avenue, Gigiri, Nairobi, Kenya; ${ }^{5}$ Department of Animal Sciences, Cornell University, Ithaca, New York 14853, USA
\end{abstract}

\begin{abstract}
In the highlands of Western Kenya, we investigated the reversibility of soil productivity decline with increasing length of continuous maize cultivation over 100 years (corresponding to decreasing soil organic carbon (SOC) and nutrient contents) using organic matter additions of differing quality and stability as a function of soil texture and inorganic nitrogen (N) additions. The ability of additions of labile organic matter (green and animal manure) to improve productivity primarily by enhanced nutrient availability was contrasted with the ability of stable organic matter (biochar and sawdust) to improve productivity by enhancing SOC. Maize productivity declined by $66 \%$ during the first 35 years of continuous cropping after forest clearing. Productivity remained at a low level of $3.0 \mathrm{t}_{\text {grain }} \mathrm{ha}^{-1}$ across the chronosequence stretching up to 105 years of continuous cultivation despite full N-phosphorus (P)-potassium (K) fertilization (120-100-100 kg $\left.\mathrm{ha}^{-1}\right)$. Application of organic resources reversed the productivity decline by increasing yields by $57-167 \%$, whereby responses to nutrient-rich
\end{abstract}

Received 28 September 2007; accepted 28 April 2008; published online 28 May 2008

*Corresponding author; e-mail: CL273@cornell.edu green manure were $110 \%$ greater than those from nutrient-poor sawdust. Productivity at the most degraded sites (80-105 years since forest clearing) increased in response to green manure to a greater extent than the yields at the least degraded sites (5 years since forest clearing), both with full $\mathrm{N}-\mathrm{P}-\mathrm{K}$ fertilization. Biochar additions at the most degraded sites doubled maize yield (equaling responses to green manure additions in some instances) that were not fully explained by nutrient availability, suggesting improvement of factors other than plant nutrition. There was no detectable influence of texture (soils with either $11-14$ or $45-49 \%$ clay) when low quality organic matter was applied (sawdust, biochar), whereas productivity was 8,15 , and $39 \%$ greater $(P<$ $0.05)$ on sandier than heavier textured soils with high quality organic matter (green and animal manure) or only inorganic nutrient additions, respectively. Across the entire degradation range, organic matter additions decreased the need for additional inorganic fertilizer $\mathrm{N}$ irrespective of the quality of the organic matter. For low quality organic resources (biochar and sawdust), crop yields were increasingly responsive to inorganic $\mathrm{N}$ fertilization with increasing soil degradation. On the other hand, fertilizer $\mathrm{N}$ additions did not 
improve soil productivity when high quality organic inputs were applied. Even with the tested full $\mathrm{N}-\mathrm{P}-\mathrm{K}$ fertilization, adding organic matter to soil was required for restoring soil productivity and most effective in the most degraded sites through both nutrient delivery (with green manure) and improvement of SOC (with biochar).

Key words: agroecosystem; chronosequence; soil degradation; soil organic matter; soil productivity.

\section{INTRODUCTION}

Sustainable maintenance of agroecosystem productivity to feed the ever-increasing world population is currently a major challenge. This can only be achieved by increasing ecosystem productivity per unit area with minimal or no adverse environmental impacts (Vitousek and others 1997; Carpenter and others 1998; Tilman and others 2001, 2002) or opening up the unutilized marginal lands for agricultural production. For several decades, in most parts of the developing world, increased production has been attained through conversion of natural ecosystems to agriculture (Giardina and others 2000; Tilman and others 2002) instead of increasing production per unit area. The anthropogenic perturbations, which accompany this land-use change through continuous cultivation and land tillage cause an immediate and rapid loss of carbon (Davidson and Ackerman 1993; Tilman and others 2002; McLauchlan 2006; Solomon and others 2007) due to the disruption of the physical, biochemical, and chemical mechanisms of soil organic matter (SOM) stabilization exposing it to microbial degradation. In resource-limited agricultural regions, this dynamic is accompanied by a removal of crop residues for feed and fuel as well as a shortage of agricultural inputs and hence lower plant growth, leading to reduced-carbon returns by residues to soil (Lal 2006).

More than $50 \%$ of soil carbon was reported to have been lost within a decade in various ecozones around the globe (Feller and Beare 1997; Tilman and others 2002; Lemenih and others 2005; McLauchlan 2006; Rumpel and others 2006; Solomon and others 2007; Tittonell and others 2007) with possibly greater losses under warm-humid climatic conditions of tropical regions (Spaccini and others 2002). Soil organic matter decline leads to reduced cation exchange capacity (CEC) resulting in weakening of nutrient retention and supply capacity as well as water retention capacity of the soil (Lal 2006). Hence, efforts to replenish soil fertility through the application of plant nutrients in readily available forms (mainly through the use of mineral fertilizers) is offset by almost immediate leaching of the mobile nutrients into the subsoil rendering them unavailable to most crops (Hölscher and others 1997; Giardina and others 2000; Renck and Lehmann 2004).

Therefore, SOM losses are usually correlated with significant nutrient depletion (Kauffman and others 1993, 1995; Giardina and others 2000; Steiner and others 2007). This poses a great challenge to crop productivity, especially in soils with low-activity clays, such as the highly weathered and leached soils of the humid tropics (Sanchez 1976; Jones and others 1997; Steiner and others 2007) and as a consequence yields typically decline dramatically with losses in SOM (Lal 2006). Although enhanced use of mineral fertilizers could be viewed as a solution, this approach is often inefficient due to the limited ability of low-activity clay soils to retain nutrients due to low SOM contents (Lal 2006). Restoring and maintaining SOM content is thus essential to long-term crop productivity.

The linkages between decline and restoration of soil organic carbon (SOC), soil productivity and the mechanisms by which replenishment of SOC can help in regaining the soil productivity as a function of its long-term decline has not been clearly demonstrated. Reversal of soil productivity decline likely depends on the nature and extent of SOM degradation and the quality of organic matter applied. After a decade of continuous human activities, the quantity of SOC reaches a plateau, but changes in SOM quality continue (Solomon and others 2007). Polysaccharide C continues to decrease leaving highly recalcitrant aromatic structures in degraded soil systems. It may therefore be expected that additions of organic matter have different effects on soil productivity depending on the length of the cultivation.

Application of organic matter to soils also supplies needed plant nutrients that are released during decomposition (Jones and others 1997; Lehmann and others 2003; McLauchlan 2006) resulting in improved agroecosystem productivity. The recently compiled Organic Resource Database (ORD) (Palm and others 2001) can be used to select materials based on the attributes that influence nutrient release and SOM formation. High quality organic materials (such as Tithonia diversifolia 
(Hemsl.) A.Gray) are effective sources of nutrients, but may only make minor contributions to restoration of SOM (Handayanto and others 1997). Low $\mathrm{N}$-containing and highly lignified organic materials are slowly but continuously mineralized often with no evident peak in nutrient release (Cornforth and Davies 1968 as quoted by Handayanto and others 1997). Organic amendments high in polyphenols [PP] may delay nutrient release beyond the growing season when they are applied. However, the links between the quality of organic inputs and effects on reversal of ecosystem degradation need to be clearly demonstrated to enable us to more effectively restore soil fertility and land productivity. In particular, it is not clear whether the nutrient supply by added organic matter is more effective in increasing crop production than the increase in SOM.

Soil texture may influence these effects of quality of added organic matter on productivity. Nutrients from added organic matter are typically released more rapidly in sandy than in clayey soils (Bechtold and Naiman 2006). Rapid nutrient release from rapid decomposition may increase leaching losses, especially if labile organic matter is added such as legume mulches (Hagedorn and others 1997). Greater clay concentrations, on the other hand, may stabilize the organic matter and improve productivity in finer textured soils (Galvdo and others 2005; Bechtold and Naiman 2006). This may suggest that productivity can be enhanced to a greater extent by adding labile organic matter to finely textured soils than to those that are coarse. Whether this is also the case for stable organic matter additions, is less clear. In contrast, sandier soils typically have lower CEC and water holding capacity as well as SOM than finer textured soils. Additions of organic matter provide all of these benefits and may thus improve sandier soils to a greater extent (Lal 2006). Therefore, it is not clear whether productivity will be enhanced to a greater extent in finer or coarser textured soils by organic matter additions of contrasting quality.

The main aim of this study was to investigate the reversibility of soil productivity decline using organic inputs of differing quality and stability. We examined the effects of easily decomposable organic additions in comparison to very stable organic additions on plant growth and nutrition as affected by (i) duration of continuous cropping after forest clearing and hence a gradient of soil degradation and SOC contents, (ii) soil texture, and (iii) inorganic fertilizer $\mathrm{N}$ additions. We were particularly interested in how the ability of added labile organic matter to supply nutrients in comparison with the ability of added stable organic matter to increase SOM influence soil productivity as a function of soil degradation that resulted in a gradient of SOC contents.

\section{Materials ANd Methods}

\section{Site Description}

The experimental sites are located in Vihiga, Kakamega, South Nandi and North Nandi districts of western Kenya (34 $94^{\prime} 23^{\prime \prime}$ E Lat.; $00^{\circ} 13^{\prime} 44^{\prime \prime} \mathrm{N}$ Long.) with an altitude ranging between 1,542 and $1,837 \mathrm{~m}$ above sea level. The area receives about $1,800-2,146 \mathrm{~mm}$ rainfall per annum in a bimodal distribution. Long rains (LR) occur from March to August whereas short rains (SR) are from September to January. Mean annual temperature is $19^{\circ} \mathrm{C}$. The sites were part of a chronosequence experiment designed to investigate the long-term effects of land conversion from primary forest to continuous agriculture (Solomon and others 2007; Kinyangi 2008; Ngoze and others unpublished manuscript). Two chronosequences (where time is substituted by space, Huggett 1998) were established on farmers' fields on two parent materials with similar soil type for each of the two chronosequences studied and similar climate for all sites. Climate varied only slightly between the sites (Table 1), but an effect of climate and weather variability between sites on crop growth cannot be entirely excluded. Farms of different time since conversion were in close proximity from about $100 \mathrm{~m}$ to several kilometers with often similar distances between farms of the same time since conversion (Kinyangi 2008). Soil texture was comparable between forest sites, nearby recent conversions and sites that were cleared 80-105 years prior to this experiment for each of the two chronosequences. Clay contents in the A horizon (0-0.07 $\mathrm{m}$ depth) from a soil profile in the forest were $11 \%$ compared to $14 \%$ near a field that was under cultivation for 105 years. Differences in site factors were small compared to effects exerted by the duration of cultivation since forest clearance. Therefore, the site differences can be examined as effects of time since conversion (Solomon and others 2007). The time since forest clearance was identified based on official and private records, Landsat imagery, and thorough farm interviews (Kinyangi 2008). As reported by the farmers, soils received nil, or only very little inorganic fertilizer since forest clearing, no animal manure, and were always cropped with cereals (Kinyangi 2008). 
Table 1. Description of the Chronosequence Sites

\begin{tabular}{|c|c|c|c|c|c|c|}
\hline Cultivation period (years) & 0 (Forest) & 5 & 20 & 35 & 80 & 105 \\
\hline Rainfall $^{1}(\mathrm{~mm})$ & $2091(2146)$ & $2146(2100)$ & $2091(2100)$ & $2091(2100)$ & $1800(2019)$ & $1808(\mathrm{n} / \mathrm{a})$ \\
\hline Mean annual temperature ${ }^{1}\left({ }^{\circ} \mathrm{C}\right)$ & $19.0(19.9)$ & $18.9(19.9)$ & $19.0(19.9)$ & $20.0(20.6)$ & $21.0(20.1)$ & $21.0(\mathrm{n} / \mathrm{a})$ \\
\hline Altitude $^{1}$ (m a.s.l.) & $1750(1745)$ & $1803(1745)$ & $1828(1745)$ & $1837(1676)$ & $1600(1676)$ & $1542(\mathrm{n} / \mathrm{a})$ \\
\hline
\end{tabular}

To investigate the effect of soil texture, one set of experiments was established on a lighter-textured Ultisol chronosequence developed on undifferentiated Basement System rocks with 11-14\% clay, $21-27 \%$ silt, and $59-68 \%$ sand, whereas a similar set was established on a predominantly heaviertextured Ultisol developed on biotite-gneiss parent material with $45-49 \%$ clay, $15-25 \%$ silt, and $26-$ $40 \%$ sand (with the exception that no 105 year conversion was available on the sandier chronosequence). These two sets of sites were located in relatively close proximity of about 3-12 km of each other and therefore had similar climates (Table 1).

The time after forest clearing for the studied set of sites was related to decreasing SOM (Solomon and others 2007; Kinyangi 2008) as well as decreasing nutrient contents (Kinyangi 2008) and resulting lower crop yields (Ngoze and others unpublished manuscript). Therefore, time since forest clearing also represents for the investigated chronosequence, a gradient of soil degradation, as indicated by soil properties and crop productivity. Hence, sites which had been under continuous cereal production for $80-105,20-35$, and 5 years are referred to as highly, moderately, and less degraded, respectively.

To soils that had been continuously cropped with maize for 5, 20, 35, 80, and 105 years, four organic inputs ( $T$. diversifolia leaves, cattle manure, wood charcoal (thereafter referred to as biochar), and sawdust) (Table 2) were applied each season at a rate of $6 \mathrm{t} \mathrm{C} \mathrm{ha}^{-1}$ for three consecutive seasons (2005 long rains, 2005 short rains and 2006 long rains). However, for the assessment of soil productivity (maize grain yields), only data from the long rainy seasons were considered because short rainy seasons typically show low and variable productivity (Ngoze and others unpublished manuscript). The experiment was designed using a completely randomized block design with three replicate farms per conversion age. In addition to $6 \mathrm{t} \mathrm{C} \mathrm{ha}^{-1}$ added to soil as organic inputs, plots received either full fertilization with $\mathrm{N}, \mathrm{P}$, and $\mathrm{K}$ $(+\mathrm{N}$ : plot size $4 \mathrm{~m} \times 4.5 \mathrm{~m})$ at a rate of 120,100 ,
$100 \mathrm{~kg}$ per hectare, respectively, or received only $\mathrm{P}$ and $\mathrm{K}(-\mathrm{N}$; plot size $2 \mathrm{~m} \times 2.25 \mathrm{~m})$. The sites were limited to a greater extent by $\mathrm{N}$ than $\mathrm{P}$ (Ngoze and others unpublished manuscript). Plots were spotplanted with maize hybrid 614 with distances of $0.75 \mathrm{~m}$ between rows and $0.25 \mathrm{~m}$ within the row. Triple super phosphate and muriate of potash fertilizers were broadcast as a single dose at the beginning of each growing season, whereas urea application was split (one-third applied at the beginning of the growing season and two-thirds, five weeks after planting). On the $T$. diversifolia plots, freshly picked $T$. diversifolia leaves were evenly spread before incorporation using a hand hoe whereas air-dried animal manure (heaped outside a shed for about one week) obtained from a nearby veterinary farm was used in the manure plots. Biochar was produced from Eucalyptus saligna $\mathrm{Sm}$. trees using a traditional kiln method whereby wood pieces are piled together, covered with leaves and twigs, and then covered with soil allowing thermal decomposition under oxygen-deprived conditions at a temperature between 400 and $500^{\circ} \mathrm{C}$ (estimated from Schenkel and others 1998). The resulting biochar was collected in sacks, pounded into small pieces (between 1 and $20 \mathrm{~mm}$ ) which were weighed, evenly spread on the plots, and then incorporated to about $0.1 \mathrm{~m}$ depth using a hand hoe. Sawdust was obtained from a local sawmill processing mainly cypress wood, air-dried, weighed, and then applied. The control treatment with inorganic fertilizer application, but, without organic matter addition was continued from a previous study by Ngoze and others (unpublished manuscript). Depending on the rainfall intensity, weeding was done with hand hoes 2-3 times per season.

\section{Sampling and Analyses}

Maize grain and stover yields were determined in all plots at the end of each season. Stover and grain yields were measured on subplots of $3 \mathrm{~m}$ by $1.5 \mathrm{~m}$ and $1 \mathrm{~m}$ by $2.25 \mathrm{~m}$ leaving one row and one plant at the end of each row to avoid edge effects. This 
gave a net harvest area of $4.5 \mathrm{~m}^{2}$ and $2.25 \mathrm{~m}^{2}$ for $+\mathrm{N}$ plots and $-\mathrm{N}$ plots, respectively. Fresh plant material was weighed, and a representative subsample dried at $60^{\circ} \mathrm{C}$ for $48-72 \mathrm{~h}$ (until constant weight was attained) and then re-weighed. The measured weight was used to estimate maize grain yield and total biomass production per hectare. To establish the effects of application of the different OM sources on soil characteristics, soil samples were taken at the end of the third season from the topsoil $(0-0.1 \mathrm{~m})$. Sieved samples were analyzed for $\mathrm{pH}$ (in water) at the ratio of 1:2.5. Mehlich 3 soil extracts (Mehlich 1984) were analyzed for $\mathrm{Ca}, \mathrm{Mg}$, $\mathrm{K}$, and $\mathrm{P}$ by Inductively Coupled Plasma spectrometry (ICP, Spectro Ciros, Spectro A.I. Inc. MA, USA) whereas exchangeable acidity was estimated by titrating soil extracts (extracted using $1 \mathrm{~N}$ potassium chloride) against $0.01 \mathrm{~N}$ sodium hydroxide after addition of five drops of phenolphthalein indicator. Effective cation exchange capacity $\left(\mathrm{CEC}_{\text {eff }}\right)$ was estimated by adding the base cations $(\mathrm{K}, \mathrm{Ca}$, and $\mathrm{Mg}$ ) extracted by Mehlich 3 and the exchangeable acidity. In the $\mathrm{pH}$ range of 5.57.5, Mehlich 3 extractable cations are well correlated with those estimated from $\mathrm{NH}_{4}$-Ac buffered at pH 7.0 (Wang and others 2004). To estimate the entire soil cation exchange complex, potential cation exchange capacity $\left(\mathrm{CEC}_{\text {pot }}\right)$ was determined by quantifying $\mathrm{NH}_{4}$ exchanged with a $2 \mathrm{~N} \mathrm{KCl}$ on a Technicon Auto analyzer after saturating cation exchange sites with $\mathrm{NH}_{4}$-Ac buffered at $\mathrm{pH} 7.0$ (Anderson and Ingram 1993; Hendershot and others 1993). Total C and N were determined by dry combustion after fine-grinding soil sub samples with pestle and mortar. Samples were analyzed for total $\mathrm{C}$ and $\mathrm{N}$ contents with a Europa ANCA-GSL CN auto-analyzer (PDZ Europa Ltd., Sandbach, UK).

\section{Nutrient Recovery}

Nutrient uptake by maize was determined by analyzing $\mathrm{N}, \mathrm{P}, \mathrm{K}, \mathrm{Ca}$, and $\mathrm{Mg}$ in a composite sample of the entire biomass at harvest (this includes maize cob, stover, and grain). Subsamples were ovendried at $60^{\circ} \mathrm{C}$ for $48-72 \mathrm{~h}$ (until constant weight was attained) and finely ground for wet digestion with $70 \%$ nitric acid and 30\% hydrogen peroxide on a heating block (Oliva and others 2003). Phosphorus, $\mathrm{K}, \mathrm{Ca}$, and $\mathrm{Mg}$ were determined by Inductively Coupled Plasma (ICP, Spectro Ciros, Spectro A.I. Inc. MA, USA) spectrometry. Total $\mathrm{N}$ was determined by dry combustion after fine grinding plant tissue using a Cyclotec Sample Mill Tecator (model 1093, American Instrument Exchange, Inc., USA). 
Samples were analyzed for total N content with a Europa ANCA-GSL CN analyzer (PDZ Europa Ltd., Sandbach, UK).

\section{Statistical Analyses}

The statistical differences between experimental treatments and between soil degradation stages within each season were determined through Analysis of Variance (General ANOVA procedure) using GenStat version 8.2 (Rothamsted Experimental Station, 2005). Mean separation was computed using least significant difference at $P<0.05$. Productivity decline was determined following a non-linear regression model. Model equation and curve fitting were calculated in Sigma Plot for Windows, Version 9.0. This was fitted using a three-parameter single exponential decay curve:

$$
y=y_{0}+a \times \exp ^{-b x}
$$

where $y_{0}$ is the productivity equilibrium level; $a$ the productivity decline; $b$ the rate of productivity loss; $x$ the time in years.

\section{Results}

\section{Soil Productivity}

Productivity (both maize grain and total biomass yield) significantly declined by $66 \%$ during the first 35 years of cropping after forest clearance even with full inorganic fertilization (large filled dots in Figure 1; only data for grain yield shown), but remained constant for the following 70 years (Figure 1). In the highly degraded sites (80-105 years after forest conversion), the application of $\mathrm{N}, \mathrm{P}$, and $\mathrm{K}$ (major growth limiting nutrients in the study area) as synthetic fertilizers yielded a maximum of 3.0 tons of cereal grain per hectare (first year control plots, large symbols in Figure 1).

Productivity more than doubled with the addition of the easily decomposable $T$. diversifolia green biomass on those soils that had been under production for the longest period of time (105 years) in both years (to $6.7 \mathrm{t} \mathrm{ha}^{-1}$ and $8.0 \mathrm{t} \mathrm{ha}^{-1}$ in the first and second year, respectively). An increase of about $2 \mathrm{t} \mathrm{ha}^{-1}$ above the control was observed in the moderately degraded soil (20-35 years after forest clearance) with the application of $T$. diversifolia leaf biomass in both years but no significant productivity increase was noted in the less degraded soil ( 5 years after forest clearing). Manure application increased productivity by more than
$2 \mathrm{tha}^{-1}$ in both years above the control plots in the highly degraded soils. Yield increase in the moderately degraded soils was also more than $2 \mathrm{t} \mathrm{ha}^{-1}$ in the first year of cropping and $1.7 \mathrm{t} \mathrm{ha}^{-1}$ in the second year. Similar to T. diversifolia, no significant productivity increase was noted due to manure application in the less degraded sites.

Increased productivity was also observed with the application of the highly recalcitrant biochar in the highly degraded sites yielding $2.2 \mathrm{t} \mathrm{ha}^{-1}$ and $2.9 \mathrm{t} \mathrm{ha}^{-1}$ more than control plots in the first and second year, respectively. In contrast, productivity increase observed with sawdust application was minimal. Similar to the high quality organic matter, low quality organic resources did not significantly increase productivity in the less degraded sites. The absolute increase in productivity by organic matter additions was overall greater $(P<0.05)$ with progressing time of continuous agriculture (Figure 1).

\section{Effect of Soil Texture on Soil Productivity with Added Organic Matter}

Similar soil productivity was observed in both lighter and heavier textured sites with the addition of the highly recalcitrant organic matter (sawdust and biochar) (Figure 2). In contrast, productivity was significantly higher in the sandier sites

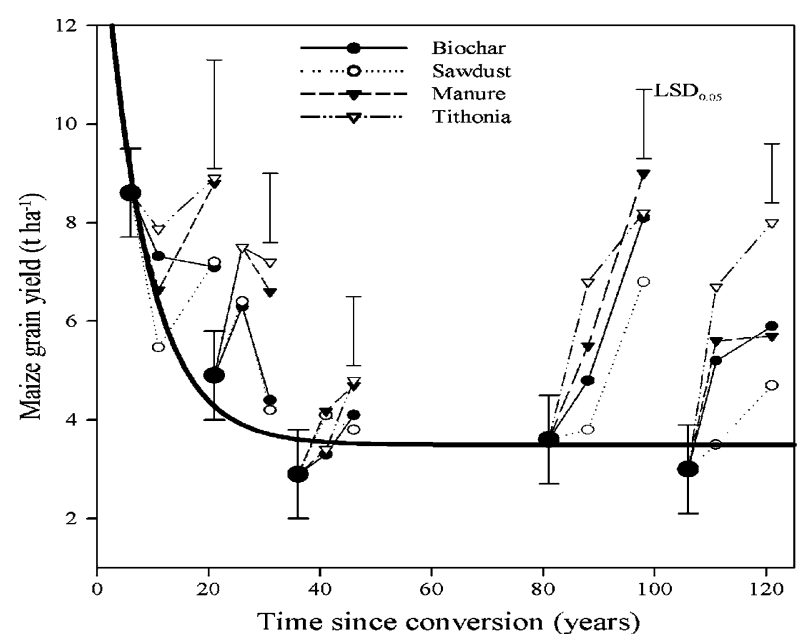

Figure 1. Influence of organic matter additions on soil productivity (maize grain yield) across a chronosequence of soil degradation in 2005-06 (heavier-textured Ultisol). Large filled circles denote cereal productivity (with full inorganic fertilization but without organic amendments). Small symbols denote productivity for two consecutive cropping seasons during long rainy seasons with different organic matter additions ( $x$ axis not to scale for small symbols). All treatments are fully fertilized. Bars represent $\operatorname{LSD}(P<0.05$ and $N=3)$. 


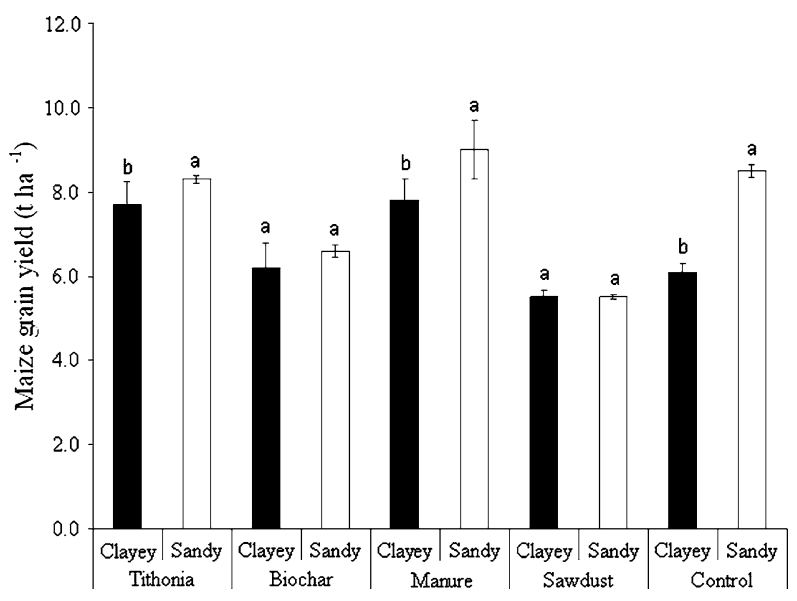

Figure 2. Organic matter additions and soil productivity at both clayey and sandy sites (error bars represent standard deviations of the mean). Comparisons are done for each treatment separately (bars with the same letter between pairs receiving the same organic amendment are not significantly different from each other; $P<0.05$ and $N=3$ ).

compared to the clayey sites with the application of high quality organic matter ( $T$. diversifolia and manure). Similarly, greater productivity on sandier soils compared with the clayey sites was observed without organic matter additions.

\section{Nitrogen Additions and Soil Productivity}

As soil degradation increased, productivity was increasingly responsive to additions of inorganic fertilizer N (Figure 3). Added organic matter increased crop productivity and, therefore, decreased the crop response to inorganic $\mathrm{N}$ additions regardless of the quality of the organic matter. For low quality organic resources (such as biochar and sawdust), added inorganic fertilizer $\mathrm{N}$ increased productivity to a greater extent as soil organic matter losses progressed over time. On the other hand, $\mathrm{N}$ additions did not improve productivity when high quality organic inputs ( $T$. diversifolia and manure) were applied (Figure 3). No differences were noted with the addition of $\mathrm{N}$ fertilizer in the less degraded sites regardless of the source of organic input.

\section{Plant Nutrition and Nutrient Uptake}

Three treatments ( $T$. diversifolia, biochar, and control) were selected for further investigation of their influence on nutrient concentrations in maize grain (Table 3) and total nutrient uptake by the entire plant (Figure 4). Without organic additions, the grain $\mathrm{N}, \mathrm{P}$, and $\mathrm{K}$ concentrations and total plant uptake decreased over time whereas $\mathrm{Ca}$ and $\mathrm{Mg}$ concentrations and uptake increased. As a result of organic matter applications ( $T$. diversifolia or biochar), plant $\mathrm{N}$ concentrations increased regardless of soil degradation (Table 3). Nitrogen concentration in the plant tissue was about $5 \mathrm{~g} \mathrm{~kg}^{-1}$ and $2 \mathrm{~g} \mathrm{~kg}^{-1}$ above the levels of the control treatment with the addition of $T$. diversifolia biomass and biochar, respectively, in the most degraded sites (Table 3). Phosphorus, K, Ca, and Mg concentrations remained unchanged or decreased on the plots with the longest continuous cropping history when organic amendments were added. Additions of labile organic matter in the form of $T$. diversifolia increased nutrient uptake for all nutrients at all stages of soil degradation. In contrast, improved nutrient uptake in response to the addition of the stable biochar was only observed for $\mathrm{Ca}(5.1 \mathrm{~kg}$ $\mathrm{ha}^{-1}$ higher than no-organic-input control) in the

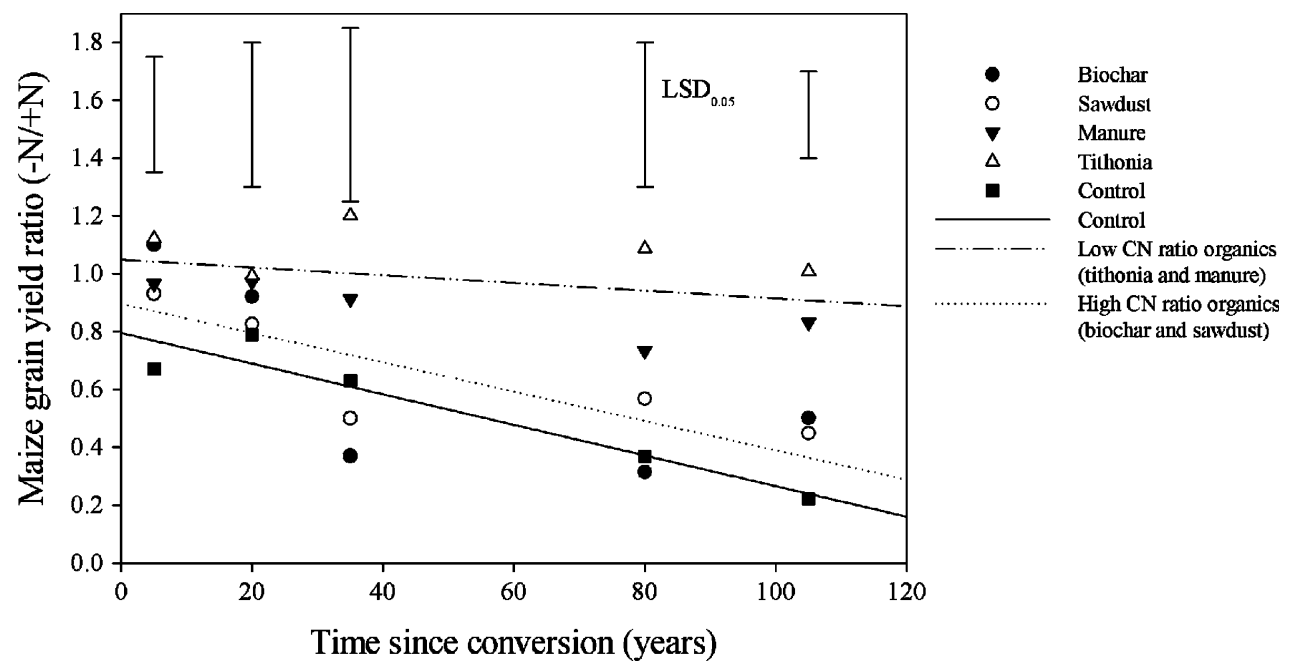

Figure 3. Nitrogen additions and cumulative soil productivity (cumulative grain yield) as a function of the duration of continuous cropping (heavier-textured Ultisol). Bars represent LSD $(P<0.05$ and $N=3)$. 
Table 3. Nutrient Concentration in the Maize Grain as a Function of Soil Degradation and the Quality of Organic Matter Additions $(N=3)$

\begin{tabular}{|c|c|c|c|c|c|c|}
\hline \multirow{2}{*}{$\begin{array}{l}\text { Years of continuous } \\
\text { anthropogenic } \\
\text { disturbances }\end{array}$} & \multirow[t]{2}{*}{ Treatment } & \multicolumn{5}{|c|}{ Nutrient concentration in maize grain $\left(\mathrm{g} \mathrm{kg}^{-1}\right)$} \\
\hline & & $\mathrm{N}$ & $P$ & K & $\mathrm{Ca}$ & $\mathrm{Mg}$ \\
\hline \multirow[t]{4}{*}{105} & T. diversifolia & $14.54 \mathrm{a}$ & $2.01 \mathrm{a}$ & $2.05 \mathrm{a}$ & $0.18 \mathrm{a}$ & $0.67 \mathrm{a}$ \\
\hline & Biochar & $11.59 \mathrm{~b}$ & $2.25 \mathrm{a}$ & $2.41 \mathrm{a}$ & $0.22 \mathrm{a}$ & $0.81 \mathrm{a}$ \\
\hline & Control & $9.65 \mathrm{c}$ & $3.28 \mathrm{a}$ & $2.74 \mathrm{a}$ & $0.22 \mathrm{a}$ & $1.09 \mathrm{a}$ \\
\hline & $\mathrm{LSD}_{0.05}$ & 0.8 & 1.6 & 0.8 & 0.06 & 0.48 \\
\hline \multirow[t]{4}{*}{35} & T. diversifolia & $15.09 \mathrm{a}$ & $3.38 \mathrm{a}$ & $3.27 \mathrm{a}$ & $0.13 \mathrm{a}$ & $1.19 \mathrm{a}$ \\
\hline & Biochar & $12.53 \mathrm{ab}$ & $2.16 \mathrm{~b}$ & $2.73 \mathrm{ab}$ & $0.12 \mathrm{a}$ & $0.79 \mathrm{~b}$ \\
\hline & Control & $11.84 \mathrm{~b}$ & $2.25 \mathrm{~b}$ & $2.56 \mathrm{~b}$ & $0.03 \mathrm{~b}$ & $0.87 \mathrm{~b}$ \\
\hline & $\mathrm{LSD}_{0.05}$ & 2.8 & 1.0 & 0.7 & 0.09 & 0.28 \\
\hline \multirow[t]{4}{*}{5} & T. diversifolia & $14.43 \mathrm{a}$ & $4.06 \mathrm{a}$ & $3.24 \mathrm{a}$ & $0.05 \mathrm{a}$ & $1.12 \mathrm{a}$ \\
\hline & Biochar & $13.89 \mathrm{ab}$ & $4.01 \mathrm{a}$ & $3.15 \mathrm{a}$ & $0.03 \mathrm{a}$ & $0.99 \mathrm{a}$ \\
\hline & Control & $13.08 \mathrm{~b}$ & $4.40 \mathrm{a}$ & $3.35 \mathrm{a}$ & $0.07 \mathrm{a}$ & $0.91 \mathrm{a}$ \\
\hline & $\mathrm{LSD}_{0.05}$ & 1.3 & 4.7 & 2.02 & 0.06 & 0.32 \\
\hline
\end{tabular}

Values followed by the same letters are not significantly different from each other at $P \leq 0.05$. Comparisons are made for each column and time point separately. LSD denotes the least significant difference.

least degraded sites. In the highly degraded sites, application of $T$. diversifolia green biomass increased total $\mathrm{N}$ uptake by more than $200 \%\left(174 \mathrm{~kg} \mathrm{ha}^{-1}\right)$ above the control whereas an increase of $9 \mathrm{~kg} \mathrm{ha}^{-1}$ was observed with the application of biochar.

An increased uptake of $12 \mathrm{~kg} \mathrm{ha}^{-1}, 131 \mathrm{~kg} \mathrm{ha}^{-1}$, $40.8 \mathrm{~kg} \mathrm{ha}^{-1}$, and $10.6 \mathrm{~kg} \mathrm{ha}^{-1}$ above the control for $\mathrm{P}, \mathrm{K}, \mathrm{Ca}$, and $\mathrm{Mg}$, respectively, was observed when $T$. diversifolia green biomass was applied in the highly degraded agroecosystems (Figure 4). In the moderately degraded sites, the uptake of all macronutrients increased by more than three times with the application of $T$. diversifolia green biomass. At these sites, biochar application did not have a significant influence on the uptake of $\mathrm{P}, \mathrm{K}, \mathrm{Ca}$, and $\mathrm{Mg}$. In the less degraded agroecosystems, total N, K and $\mathrm{Mg}$ uptake were significantly different from control treatment for $T$. diversifolia biomass application, but no significant differences were observed in the uptake of the other macronutrients.

\section{Organic Matter Additions and Soil Fertility}

Across the entire chronosequence, base saturation (BS) significantly $(P<0.05)$ increased due to organic matter additions. Improvements ranged from only a few percent points to $19-26 \%$ at the moderately degraded sites (20 years of continuous agriculture) (Table 4). Although the soil $\mathrm{pH}$ was lower in both the highly degraded sites and the moderately degraded sites (under continuous cultivation for $\geq 20$ years) compared to the less degraded sites (under continuous cultivation for 5 years), there was a significant increase in soil $\mathrm{pH}$ with the addition of organic matter across the degradation sequence.

Effective cation exchange capacity $\left(\mathrm{CEC}_{\text {eff }}\right)$ increased by $61.8 \mathrm{mmol}_{\mathrm{c}} \mathrm{kg}^{-1}$ with the addition of manure in sites which had been cultivated for 20 years whereas application of $T$. diversifolia biomass, sawdust, and biochar increased $\mathrm{CEC}_{\text {eff }}$ by $49.4,43.8$, and $38.7 \mathrm{mmol}_{\mathrm{c}} \mathrm{kg}^{-1}$, respectively, above control plots in these moderately degraded sites. Additions of manure in the highly degraded sites (under continuous cultivation for $>100$ years) increased $\mathrm{CEC}_{\text {eff }}$ by almost $60 \mathrm{mmol}_{\mathrm{C}} \mathrm{kg}^{-1}$ whereas T. diversifolia, sawdust, and biochar plots had 41.7, 26.2 , and $22.7 \mathrm{mmol}_{\mathrm{c}} \mathrm{kg}^{-1}$, respectively, higher $\mathrm{CEC}_{\text {eff }}$ than control plots. No effect was observed in the less degraded sites with the application of the different organic resources.

Addition of organic matter had a significant effect $(P<0.05)$ on the potential cation exchange capacity $\left(\mathrm{CEC}_{\text {pot }}\right)$ only in the highly degraded sites where application of $T$. diversifolia biomass increased $\mathrm{CEC}_{\text {pot }}$ by $24.3 \mathrm{mmol}_{\mathrm{c}} \mathrm{kg}^{-1}$ whereas manure, sawdust, and biochar additions increased $\mathrm{CEC}_{\text {pot }}$ by a smaller margin $(20.8,17.6$, and $11.8 \mathrm{mmol}_{\mathrm{c}} \mathrm{kg}^{-1}$, respectively) above control plots without organic matter additions. No significant effects were observed on the $\mathrm{CEC}_{\text {pot }}$ in the moderately and the less degraded sites regardless of the type of organic input added.

Soil organic carbon significantly increased $(P<0.05)$ with the application of the different organic resources in the highly degraded agroecosystems. Application of biochar had the highest impact with a $45 \%$ increase above control plots 

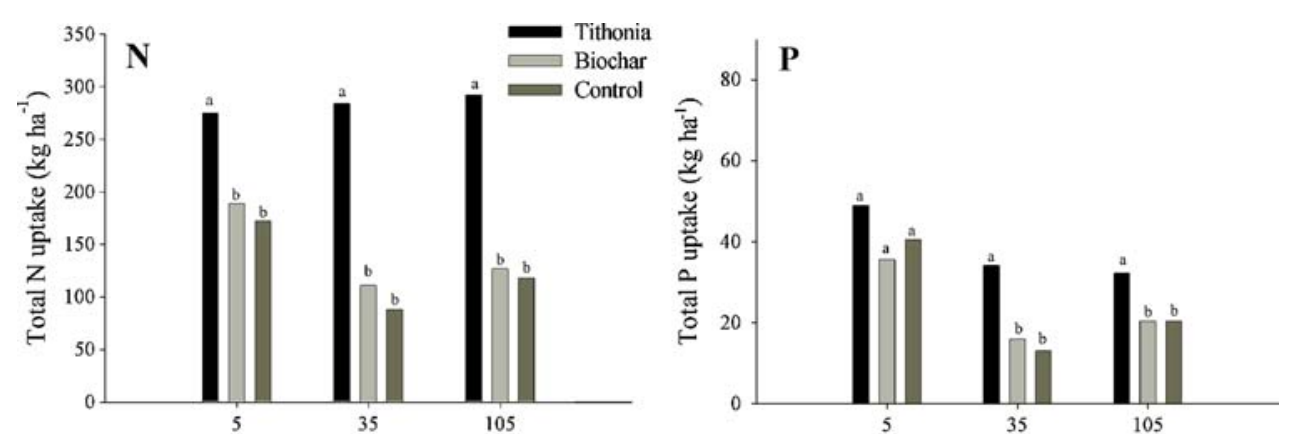

Figure 4. Total nutrient uptake by maize as a function of soil degradation and the quality of organic matter additions (bars with the same letter within the same conversion age are not significantly different from each other; $P<0.05$ and $N=3$ ).
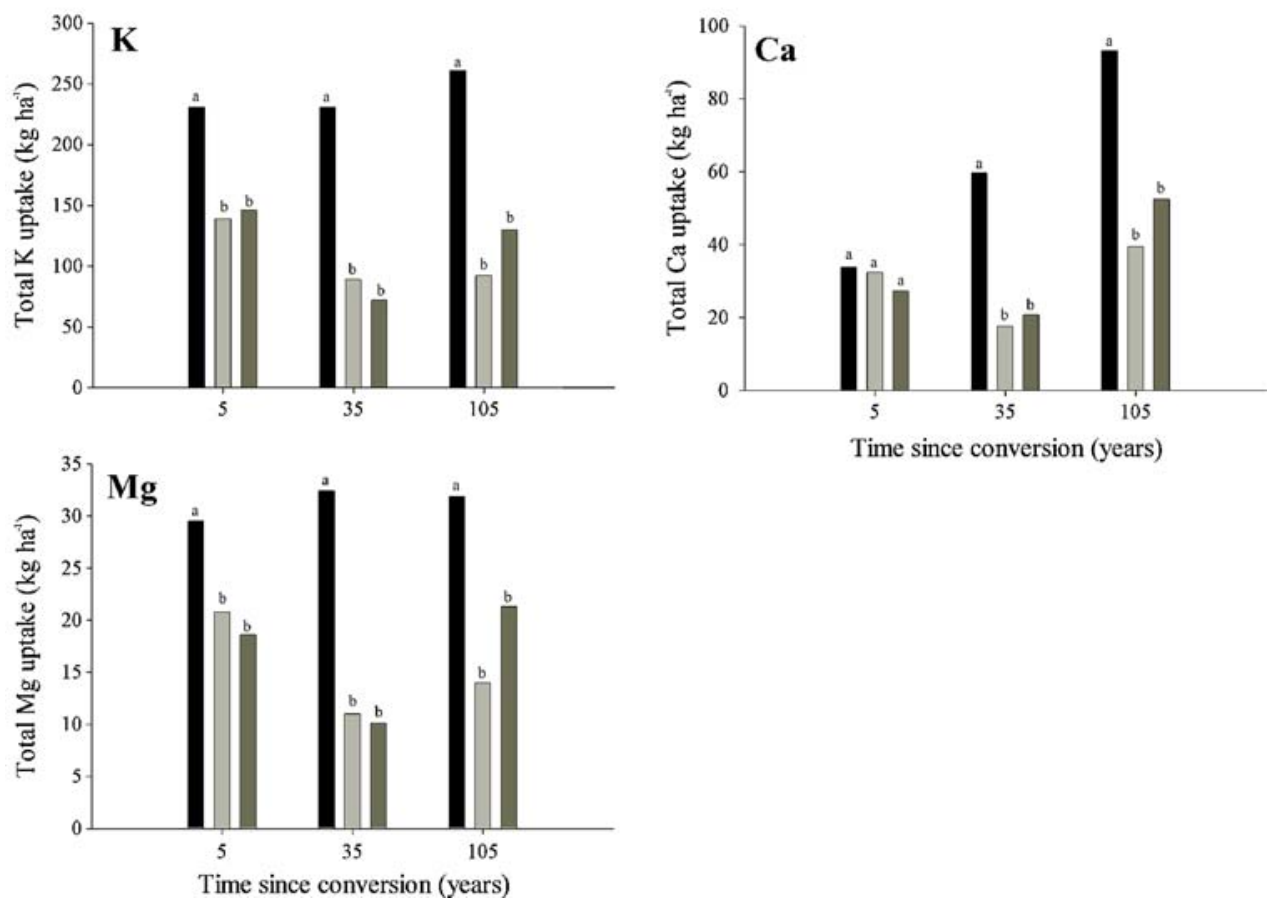

Time since conversion (years)

whereas manure and $T$. diversifolia increased SOC by $27 \%$. Sawdust had the lowest impact with only $24 \%$ increase in SOC above control plots. No significant increase in SOC was observed in the SOM-rich and moderately degraded agroecosystems regardless of the quality of the added organic matter.

\section{Discussion}

\section{Chemical Stability versus Nutrient Delivery of Organic Amendments}

Organic amendments can not only help to increase SOC, but also act as a source of plant available nutrients thereby presenting two opposing paradigms: building soil nutrient stocks and carbon cycles in soil with easily degradable organic matter versus very stable organic matter that does not readily release nutrients, but may contribute to the increasing SOC. High quality organic materials (such as $T$. diversifolia and manure) are effective sources of nutrients (Gachengo and others 1999; Jama and others 2000; Lehmann and others 2001; Palm and others 2001) helping to immediately improve the productivity level of an ecosystem. The high nutrient contents (especially $\mathrm{N})(>4.0 \%)$ (Table 2) which are above the critical $\mathrm{N}$ limit for net N mineralization (Nourbakhsh and Dick 2005) coupled with the low C-to-N ratio $(<10)$ of the $T$. diversifolia biomass result in rapid microbial degradation with a reported half life of about one week (Gachengo and others 1999). Hence, most of the nutrients in $T$. diversifolia have most likely been released rapidly for immediate utilization by the growing crops. The same applies to the manure used in this study, which is considered to be of high quality with $22 \mathrm{mg} \mathrm{g}^{-1} \mathrm{~N}$ and a C-to-N ratio of 15 . An immediate benefit for plant productivity from the use of high quality organic resources has been demonstrated in numerous studies (Jama and others 2000; Kimetu and others 2004). As a consequence, improved nutrient uptake was observed with addition of $T$. diversifolia (Figure 4). However, 
Table 4. Impact of Organic Inputs on Soil Effective Cation Exchange Capacity ( $\left.\mathrm{CEC}_{\mathrm{eff}}\right)$, Potential Cation Exchange Capacity $\left(\mathrm{CEC}_{\mathrm{pot}}\right)$, Base Saturation, SOC and $\mathrm{pH}$ at the Clayey Sites $(N=3)$

\begin{tabular}{|c|c|c|c|c|c|c|}
\hline $\begin{array}{l}\text { Years of } \\
\text { cultivation }\end{array}$ & Treatment & $\%$ BS & $\mathrm{pH}_{\text {water }}(1: 2.5)$ & $\mathrm{CEC}_{\text {eff }}\left(\mathrm{mmol}_{\mathrm{c}} \mathrm{kg}^{-1}\right)$ & $\mathrm{CEC}_{\text {pot }}\left(\mathrm{mmol}_{\mathrm{c}} \mathrm{kg}^{-1}\right)$ & SOC $\left(\mathrm{g} \mathrm{kg}^{-1}\right)$ \\
\hline \multirow[t]{6}{*}{105} & Biochar & $98.9 \mathrm{~b}$ & $6.1 \mathrm{ab}$ & $138.6 \mathrm{~b}$ & $273.5 \mathrm{~b}$ & $30.5 \mathrm{a}$ \\
\hline & Sawdust & $99.0 \mathrm{ab}$ & $6.0 \mathrm{~b}$ & $142.1 \mathrm{~b}$ & $279.3 \mathrm{ab}$ & $26.2 \mathrm{~b}$ \\
\hline & Manure & $99.5 \mathrm{a}$ & $6.3 \mathrm{a}$ & $171.5 \mathrm{a}$ & $282.5 \mathrm{ab}$ & $26.9 \mathrm{ab}$ \\
\hline & T. diversifolia & $99.2 \mathrm{ab}$ & $6.2 \mathrm{a}$ & $157.6 \mathrm{ab}$ & $286.0 \mathrm{a}$ & $26.8 \mathrm{ab}$ \\
\hline & Control & $98.1 \mathrm{c}$ & $5.9 \mathrm{~b}$ & $115.9 \mathrm{c}$ & $261.7 \mathrm{c}$ & $21.1 \mathrm{C}$ \\
\hline & $\mathrm{LSD}_{0.05}$ & 0.6 & 0.30 & 19.2 & 9.2 & 3.8 \\
\hline \multirow[t]{6}{*}{35} & Biochar & $98.3 \mathrm{~b}$ & $5.6 \mathrm{ab}$ & $107.1 \mathrm{ac}$ & $205.3 \mathrm{a}$ & $30.1 \mathrm{a}$ \\
\hline & Sawdust & $96.7 \mathrm{c}$ & $5.4 \mathrm{~b}$ & 86.6 b & $185.0 \mathrm{a}$ & $26.5 \mathrm{ab}$ \\
\hline & Manure & $99.1 \mathrm{a}$ & $5.9 \mathrm{a}$ & $119.7 \mathrm{a}$ & $193.9 \mathrm{a}$ & $29.1 \mathrm{a}$ \\
\hline & T. diversifolia & $98.2 \mathrm{~b}$ & $5.6 \mathrm{ab}$ & $111.3 \mathrm{a}$ & $208.2 \mathrm{a}$ & 30.7 a \\
\hline & Control & $96.3 \mathrm{c}$ & $5.5 \mathrm{~b}$ & 90.6 bc & $186.7 \mathrm{a}$ & $21.7 \mathrm{~b}$ \\
\hline & $\mathrm{LSD}_{0.05}$ & 0.7 & 0.32 & 19.2 & 30.0 & 7.0 \\
\hline \multirow[t]{6}{*}{20} & Biochar & $89.2 \mathrm{a}$ & $5.7 \mathrm{a}$ & $86.0 \mathrm{ab}$ & $206.9 \mathrm{a}$ & $36.4 \mathrm{ab}$ \\
\hline & Sawdust & $89.0 \mathrm{a}$ & $5.7 \mathrm{a}$ & $91.1 \mathrm{a}$ & $209.7 \mathrm{a}$ & $39.2 \mathrm{a}$ \\
\hline & Manure & $96.3 \mathrm{a}$ & $6.0 \mathrm{a}$ & $109.1 \mathrm{a}$ & $208.2 \mathrm{a}$ & $36.4 \mathrm{ab}$ \\
\hline & T. diversifolia & $94.2 \mathrm{a}$ & $5.7 \mathrm{a}$ & $96.7 \mathrm{a}$ & $214.7 \mathrm{a}$ & $32.6 \mathrm{~b}$ \\
\hline & Control & $70.2 \mathrm{~b}$ & $5.2 \mathrm{~b}$ & $47.3 \mathrm{~b}$ & $170.2 \mathrm{a}$ & $32.6 \mathrm{~b}$ \\
\hline & $\mathrm{LSD}_{0.05}$ & 9.2 & 0.32 & 42.4 & 48.0 & 5.0 \\
\hline \multirow[t]{6}{*}{5} & Biochar & 99.9 a & $7.1 \mathrm{a}$ & $265.0 \mathrm{a}$ & $292.2 \mathrm{a}$ & $64.9 \mathrm{a}$ \\
\hline & Sawdust & $99.8 \mathrm{~b}$ & $6.5 \mathrm{a}$ & $271.0 \mathrm{a}$ & $325.5 \mathrm{a}$ & $65.5 \mathrm{a}$ \\
\hline & Manure & 99.7 c & $6.9 \mathrm{a}$ & $287.0 \mathrm{a}$ & $327.8 \mathrm{a}$ & $65.5 \mathrm{a}$ \\
\hline & T. diversifolia & $99.8 \mathrm{~b}$ & $6.4 \mathrm{a}$ & $238.0 \mathrm{a}$ & $315.8 \mathrm{a}$ & $60.2 \mathrm{a}$ \\
\hline & Control & $99.6 \mathrm{~d}$ & $6.3 \mathrm{a}$ & $235.0 \mathrm{a}$ & $320.3 \mathrm{a}$ & 59.9 a \\
\hline & $\mathrm{LSD}_{0.05}$ & 0.08 & 1.0 & 71.8 & 40.0 & 13.0 \\
\hline
\end{tabular}

Values followed by the same letter do not differ at $P \leq 0.05$. Comparisons are made for each column and time point separately. LSD denotes the least significant difference.

there is normally little contribution to long-term SOM levels when such high quality organics are used for land productivity improvement (Handayanto and others 1997; Lehmann and others 2001).

In contrast, the low quality organic matter additions (sawdust and biochar) appear to have contributed very little to the availability of nutrients by mineralization and nutrient release. Some decomposition of both sawdust and biochar may have occurred and nutrients may have leached from the organic matter without microbial decay. For example, Cheng and others (2006) reported the oxidation of the more labile alkyl carbon forms in biochar during a 4-month incubation. In addition, biochar may contain some base cations (mainly K) that become available in the short term (Lehmann and others 2003). However, any microbial decomposition may have rather decreased availability of $\mathrm{N}$ by immobilization, because the C-to- $\mathrm{N}$ ratios of both sawdust and biochar were high (Table 2). Yet, the nutrient concentrations in the grain of the maize that received biochar (Table 3 ) did not suggest $\mathrm{N}$ immobilization, but rather a net increase in $\mathrm{N}$ availability, which relates well to the supposedly high recalcitrance of biochar against microbial decay (Schmidt and Noack 2000). Decomposition of biochar was probably minimal and therefore significant $\mathrm{N}$ immobilization may not have occurred. Any long-term effects of biochar on plant nutrition may probably not relate to its direct nutrient contributions, but rather to its effects on nutrient retention through improved CEC (Glaser and others 2002; Liang and others 2006; Yamato and others 2006). However, during the two years of observation, the biochar additions only slightly improved plant nutrition (significant for $\mathrm{N}$ only in highly degraded soils). The question remains, in what way did biochar treatment improve productivity if not by improving nutrient availability. An observed improvement in $\mathrm{CEC}, \mathrm{pH}$, and base saturation (Table 4) may have played a role at some sites, although to a limited extent. Additional possible explanations that were not tested here include effects of biochar on plant-available soil water or microbial populations and dynamics (Lehmann and Rondon 2006), which would need to be verified.

In contrast to biochar, which is very stable, sawdust typically decomposes albeit at a slow rate 
(Cornforth and Davies 1968 as quoted by Handayanto and others 1997; Roose and Barthès 2001) causing a delayed release of nutrients often beyond the current growing season. The decomposition of sawdust may have caused $\mathrm{N}$ immobilization due to its high C-to-N ratio, or due to inhibitory effects on microbial activity exerted by secondary plant compounds. The weak improvement in productivity from sawdust applications and the much greater improvement of productivity as a response to biochar additions suggests that these two organic materials act very differently in soil despite their similar C-to-N ratios. This could be related to the greater decomposability of sawdust which may lead to $\mathrm{N}$ immobilization in contrast to biochar as explained above, to greater nutrient retention by biochar (Liang and others 2006), or to biological effects that have been hypothesized to occur in biochar-amended soils (Lehmann and Rondon 2006; Warnock and others 2007).

Recalcitrant organic materials typically have more substantial long-term benefits through their contributions to SOM (Palm and others 2001; Lehmann and others 2001). After two years of additions of 6 tons $\mathrm{C} \mathrm{ha}^{-1}$ per cropping season, additions of biochar increased SOC by $45 \%$ whereas $T$. diversifolia and sawdust increased SOC by only 27 and $25 \%$, respectively, in the soils with the lowest amount of SOC. Due to its recalcitrance against microbial degradation (Schmidt and Noack 2000) biochar is very stable in soil compared to other organic matter additions making it a suitable approach for the build-up of SOC. In the less degraded soils with already high SOC levels, the SOC increase due to organic matter additions was insignificant, which may be an indication that C saturation (Six and others 2002) was reached or may reflect a methodological challenge of detecting a comparatively low amount of $\mathrm{C}$ added to a large SOC pool.

\section{Reversibility of Productivity Decline}

The use of organic resources significantly improved soil productivity and was able to reverse declines in crop productivity. Productivity increases varied with the type of organic amendment and nearly doubled in some cases whereas being negligible in others. The improvements were over and above the productivity improvements that were achieved through applications of inorganic $\mathrm{N}, \mathrm{P}$, and $\mathrm{K}$ fertilizer applied at recommended rates, and reached levels even at the most degraded sites that were achieved at the most fertile sites. Therefore, the tested combination of inorganic and organic additions was able to nearly restore the productive capacity of the soils within only three cropping seasons of continuous applications with $6 \mathrm{t} \mathrm{C} \mathrm{ha}^{-1}$ per season. Various mechanisms may be responsible for improved productivity by organic matter additions like increased moisture retention (Wallace 1996; Lehmann and others 1999), weed suppression (Kimetu and others 2004), or supply of nutrients (Murwira and others 2002). In addition, synergistic effects of applications of organic and inorganic amendments (Jenkinson 1991; Palm and others 1997; Kimetu and others 2004; Das and others 2004) may have played a role, such as, improved uptake of fertilizer nutrients by enhanced organic matter contents through increased soil water or CEC. The greatest productivity increase by $57-167 \%$ was observed in the most degraded sites, whereas productivity in moderately degraded sites only improved with T. diversifolia and manure by 65 and $56 \%$, respectively. No increase was observed in the least degraded sites with any amendment. Therefore, resource allocation for securing or restoring soil productivity was most effective in the most degraded sites. Our results suggest that efforts to alleviate soil degradation and to restore productivity should be concentrated on the most degraded sites and have to include organic amendments under the inorganic fertilization regimes used here.

The observation period was too short to discern from a biophysical point of view whether optimizing for improvement of soil organic matter quantity or for nutrient release is in the long term the superior approach. In the short term, nutrient supply appeared to be slightly more important in this study. However, doubled yield with biochar over the control was not fully explained by enhanced crop nutrition, suggesting that improving SOC contents significantly enhanced crop yields.

\section{Effects of Soil Texture on Reversibility of Productivity Decline}

Soil organic carbon in response to OM additions increased differently as a function of soil texture and stage of soil degradation. Application of biochar increased SOC by $45 \%$ whereas manure and $T$. diversifolia only increased SOC by $27 \%$ in the SOM-poor clayey sites. In the SOM-poor sandy sites biochar application increased SOC by almost the same magnitude (38\% increase) whereas manure and Tithonia increased SOC by a narrower margin $(19 \%$ and $9 \%$, respectively; data not shown) compared with the clayey sites. The soil texture influences SOC storage, stabilization, and 
aggregate stability (Chaney and Swift 1984; Schlecht-Pietsch and others 1994; Plante and others 2006) mainly through direct and indirect effects on the physical and chemical protection of soil organic matter (Plante and others 2006). Therefore, improved plant productivity observed with the high quality OM in the sandier sites compared with the clayey sites could be attributed to the high mineralization rate in the sandy sites resulting in immediate nutrient release for plant growth. In the clayey sites, on the other hand, microbial degradation of labile OM may have been reduced or delayed, thereby decreasing nutrient release from the decomposing OM. Nutrient delivery may therefore have been more important than SOC increase for the labile OM additions.

\section{Nitrogen Effects on Reversibility of Productivity Decline}

At the same sites where the current study was done, crop responses to increasing fertilizer $\mathrm{N}$ additions from 30 to 60,90 , and $120 \mathrm{~kg} \mathrm{ha}^{-1}$ suggested that more than $120 \mathrm{~kg} \mathrm{ha}^{-1}$ are required for optimum growth in the long rainy season (Ngoze and others unpublished manuscript). Therefore, it is not surprising that $\mathrm{N}$ applications by inorganic fertilizers improved productivity for organic matter additions that do not release $\mathrm{N}$ and rather enhanced SOC stocks such as biochar and sawdust. However, additional application of inorganic $\mathrm{N}$ was not required to reach maximum productivity, when high quality organic matter such as $T$. diversifolia and manure was used. This result confirms earlier studies that inorganic $\mathrm{N}$ additions can be fully substituted by organic $\mathrm{N}$ additions if the appropriate source of organic matter is applied as in the case of $T$. diversifolia (Kimetu and others 2004; Ngoze and others unpublished manuscript). On the other hand, inorganic $\mathrm{N}$ additions are required if organic additions are used to improve SOC levels rather than to add $\mathrm{N}$ as in the case of biochar. Several studies have demonstrated that soil productivity can be substantially increased with the application of biochar in a fully fertilized soil with $\mathrm{N}, \mathrm{P}, \mathrm{K}$ compared to soils that received only N, P, K application (Yamato and others 2006; Steiner and others 2007).

Additional inorganic $\mathrm{N}$ fertilization to applications of stable $\mathrm{OM}$ increased productivity to a lesser degree when soil degradation is low within 20 years of continuous cultivation after conversion from primary forest. There appears to be a lower motivation for $\mathrm{N}$ buildup at early stages of soil degradation to improve productivity, because soil $\mathrm{N}$ contents were still high. The increasing need for $\mathrm{N}$ with time can be explained by the continuing soil degradation, although total $\mathrm{C}$ (Table 4) and total $\mathrm{N}$ contents as well as $\mathrm{C}$ and $\mathrm{N}$ stocks (Solomon and others 2007; Kinyangi, 2008) did not change beyond 20 years of continuous cultivation. This may be related to the changes in organic matter quality (Solomon and others 2007; Kinyangi 2008), which continued beyond 20 years and may have had an effect on soil productivity.

\section{Conclusions}

We showed that organic matter additions are in principle able to fully restore soil productivity to levels observed before degradation started. During the period of this study, beneficial effects of organic matter additions were slightly better related to their nutrient release and subsequent improvements of crop nutrition than to their improvement of SOM. However, crop yield responses to increasing SOM were significant and could not be fully explained with improved nutrition as in the case of biochar. These effects require further studies.

The short observation period does not allow projections to long-term effects of organic matter additions at different stages of soil degradation. Over the nearly two years examined in this study, the stability of organic matter played a significant, but less important role than nutrient release from decomposing organic matter in improving and restoring productivity in the studied soils. Longerterm observations are required to fully understand the sustainability of stable organic matter additions in reverting soil degradation.

\section{ACKNOWLEDGMENTS}

This material is based upon work supported by the National Science Foundation under grant No. 0215890 and the Rockefeller Foundation under grant No. 2004 FS 104. Any opinions, findings, and conclusions or recommendations expressed in this material are those of the author(s) and do not necessarily reflect the views of the National Science Foundation. Additional financial support was provided by the Presbyterian Fund of Ithaca, Cornell University and the Mario Einaudi Center for International Studies. Field and laboratory technicians were instrumental in the implementation of this work and their work is very much appreciated. The support we received from Dr. David Mbugua in coordinating the work both in the field and in the lab is thankfully acknowledged. Many thanks to 
the Lehmann lab group for their encouragement and moral support throughout this study.

\section{REFERENCES}

Anderson JM, Ingram JSI. 1993. Tropical soil biology and fertility: a handbook of methods. Wallingford, Oxon, UK: CAB International.

Bechtold JS, Naiman RJ. 2006. Soil texture and nitrogen mineralization potential across a riparian toposequence in a semiarid savanna. Soil Biol Biochem 38:1325-33.

Carpenter SR, Caraco NF, Correll DL, Howarth RW, Sharpley AN, Smith VH. 1998. Nonpoint pollution of surface waters with phosphorus and nitrogen. Ecol Appl 8:559-68.

Chaney K, Swift RS. 1984. The influence of organic matter on aggregate stability in some British soils. J Soil Sci 35:223-30.

Cheng CH, Lehmann J, Thies JE, Burton SD, Engelhard MH. 2006. Oxidation of black carbon by biotic and abiotic processes. Org Geochem 37:1477-88.

Cornforth IS, Davies JB. 1968. Nitrogen transformations in tropical soils. I. the mineralization of nitrogen-rich organic materials added to soil. Trop Agric (Trinidad) 45:211-21.

Das A, Prasad M, Shivay YS, Subha KM. 2004. Productivity and sustainability of cotton (Gossypium hirsutum L.)-wheat (Triticum aestivum L.) cropping system as influenced by prilled urea, farmyard manure and azotobacter. J Agron Crop Sci 190: 298-304.

Davidson EA, Ackerman IL. 1993. Changes in soil carbon inventories following cultivation of previously untilled soils. Biogeochem 20:161-93.

Feller C, Beare MH. 1997. Physical control of soil organic matter dynamics in the tropics. Geoderma 79:69-116.

Gachengo CN, Palm CA, Jama B, Othieno C. 1999. Tithonia and senna green manures and inorganic fertilisers as phosphorus sources for maize in western Kenya. Agrofor Syst 44:21-36.

Galvdo SRD, Salcedo IH, dos Santos AC. 2005. Carbon and nitrogen fractions as affected by texture, relief and land use in the VACA brava watershed. Rev Bras de Ci do Solo 29:955-62.

Giardina CP, Sanford RL, Dockersmith IC, Jaramillo VJ. 2000. The effects of slash burning on ecosystem nutrients during the land preparation phase of shifting cultivation. Plant Soil 220:247-60.

Glaser B, Lehmann J, Zech W. 2002. Ameliorating physical and chemical properties of highly weathered soils in the tropics with charcoal: a review. Biol Fertil Soils 35:219-30.

Hagedorn F, Steiner KG, Sekayange L, Zech W. 1997. Effect of rainfall pattern on nitrogen mineralization and leaching in a green manure experiment in Rwanda. Plant Soil 195:365-75.

Handayanto E, Cadisch G, Giller KE. 1997. Regulating N mineralization from plant residues by manipulation of quality. In: Cadisch G, Giller KE, Eds. Driven by nature: plant litter quality and decomposition. Wallingford, UK: CAB International. pp 175-185.

Hendershot WH, Lalande H, Duquette M. 1993. Ion exchange and exchangeable cations. In: Carter MR, Ed. Soil sampling and methods of analysis. Canadian Society of Soil Science. Boca Raton, USA: Lewis Publishers. pp 167-176.

Hölscher D, Ludwig B, Möller RF, Fölster H. 1997. Dynamic of soil chemical parameters in shifting agriculture in the Eastern Amazon. Agric Ecosyst Environ 66:153-63.
Huggett RJ. 1998. Soil chronosequences, soil development, and soil evolution: a critical review. Catena 32:155-172.

Jaetzold R, Schmidt H, Hornetz B, Shisanya C. 2007. Farm management handbook of Kenya VOL. II - Natural conditions and farm management information - 2nd Edition Part A: West Kenya. Subpart Al: Western Province. Ministry of Agriculture, Kenya, in Cooperation with the German Agency for Technical Cooperation (GTZ).

Jama B, Palm CA, Buresh RJ, Niang A, Gachengo C, Nziguheba G, Amadalo B. 2000. Tithonia diversifolia as a green manure for soil fertility improvement in western Kenya: a review. Agrofor Syst 49:201-21.

Jenkinson DS. 1991. The Rothamsted long-term experiments: are they still of use? Agron J 83:2-10.

Jones RB, Snapp SS, Phombeya HSK. 1997. Management of leguminous leaf residues to improve nutrient use efficiency in the sub-humid tropics. In: Cadisch G, Giller KE, Eds. Driven by nature: plant litter quality and decomposition. Wallingford, UK: CAB International. pp 239-250.

Kauffman JB, Sanford R Jr, Cummings D, Salcedo I, Sampaio. 1993. Biomass and nutrient dynamics associated with slash fires in neotropical dry forests. Ecology 74:140-51.

Kauffman JB, Cummings D, Ward D, Babbitt R. 1995. Fire in the Brazilian Amazon: 1. Biomass, nutrient pools and losses in slashed primary forests. Oecologia (Berlin) 104:397-408.

Kimetu JM, Mugendi DN, Palm CA, Mutuo PK, Gachengo CN, Bationo A, Nandwa S, Kungu JB. 2004. Nitrogen fertilizer equivalencies of organic materials of differing quality and optimum combination with inorganic nitrogen sources in Central Kenya. Nutr Cycl Agroecosyst 68:127-35.

Kinyangi J. 2008. Soil degradation, thresholds and dynamics of long-term cultivation: From landscape biogeochemistry to nanoscale biogeocomplexity. PhD dissertation, Cornell University. 172 pp.

Lal R. 2006. Enhancing crop yields in the developing countries through restoration of the soil organic carbon pool in agricultural lands. Land Degrad Develop 17:197-209.

Lehmann J, Rondon M. 2006. Biochar soil management on highly weathered soils in the humid tropics. In: Uphoff $\mathrm{N}$ and others, Eds. Biological approaches to sustainable soil systems. Boca Raton, FL, USA: CRC Press, Taylor \& Francis Group. pp 517-30.

Lehmann J, Feilner T, Gebauer G, Zech W. 1999. Nitrogen uptake of sorghum (Sorghum bicolor L.) from tree mulch and mineral fertilizer under high leaching conditions estimated by nitrogen-15 enrichment. Biol Fertil Soils 30:90-5.

Lehmann J, Cravo MS, Zech W. 2001. Organic matter stabilization in a Xanthic Ferralsol of the central Amazon as affected by single trees: chemical characterization of density, aggregate, and particle size fractions. Geoderma 99:147-68.

Lehmann J, da Silva J P Jr, Steiner C, Nehls T, Zech W, Glaser B. 2003. Nutrient availability and leaching in an archaeological Anthrosol and a Ferralsol of the Central Amazon basin: fertilizer, manure and charcoal amendments. Plant Soil 249:343-57.

Lemenih M, Karltun E, Olsson M. 2005. Soil organic matter dynamics after deforestation along a farm field chronosequence in southern highlands of Ethiopia. Agric Ecosyst Environ 109:9-19.

Liang B, Lehmann J, Solomon D, Kinyangi J, Grossman J, O'Neill B, Skjemstad JO, Thies J, Luizão FJ, Petersen J, Neves EG. 2006. Black carbon increases cation exchange capacity in soils. Soil Sci Soc Am J 70:1719-30. 
McLauchlan K. 2006. The nature and longevity of agricultural impacts on soil carbon and nutrients: a Review. Ecosystems 9:1364-82.

Mehlich A. 1984. Mehlich 3 Soil Test Extractant: A modification of Mehlich 2 Extractant. Commun Soil Sci Plant Anal 15:1409-16.

Murwira HK, Mutuo PK, Nhamo N, Marandu AE, Rabeson R, Mwale M, Palm CA. 2002. Fertilizer equivalency values of organic materials of differing quality. In: Vanlauwe B, Diels J, Sanginga N, Merckx R, Eds. Integrated plant nutrient management in sub-Saharan Africa. Wallingford, UK: CABI Publishing. pp 113-22.

Nourbakhsh F, Dick RP. 2005. Net nitrogen mineralization or immobilization potential in a residue-amended calcareous soil. Arid Land Res Manag 19:299-306.

Oliva SR, Raitio H, Mingorance MD. 2003. Comparison of two wet digestion procedures for multi-element analysis of plant samples. Commun Soil Sci Plant Anal 34:2913-23.

Palm CA, Myers RJK, Nandwa SM. 1997. Combined use of organic and inorganic nutrient sources for soil fertility maintenance and replenishment. In: Buresh RJ, Sanchez PA, Eds. Replenishing soil fertility in Africa. SSSA Special Publication 51. Madison, WI: SSSA. pp 193-217.

Palm CA, Gachengo CN, Delve RJ, Cadisch G, Giller KE. 2001. Organic inputs for soil fertility management in tropical agroecosystems: application of an organic resource database. Agric Ecosyst Environ 83:27-42.

Plante AF, Conant RT, Stewart CE, Paustian K, Six J. 2006. Impact of soil texture on the distribution of soil organic matter in physical and chemical fractions. Soil Sci Soc Am J 70:287-96.

Renck A, Lehmann J. 2004. Rapid water flow and transport of inorganic and organic nitrogen in a highly aggregated tropical soil. Soil Sci 169:330-41.

Roose E, Barth'es B. 2001. Organic matter management for soil conservation and productivity restoration in Africa: A contribution from Francophone research. Nutr Cycl Agroecosyst 61:159-70.

Rothamsted Experimental Station. 2005. GenStat for Windows Version 8.2. UK.

Rumpel C, Alexis M, Chabbi A, Chaplot V, Rasse DP, Valentin C, Mariotti A. 2006. Black carbon contribution to soil organic matter composition in tropical sloping land under slash and burn agriculture. Geoderma 130:35-46.

Sanchez PA. 1976. Properties and management of soils in the tropics. New York, NY, USA: Wiley.

Schenkel Y, Bertaux P, Vanwijnbserghe S, Carre J. 1998. An evaluation of the mound kiln carbonization technique. Biom Bioenergy 14:505-16.

Schlecht-Pietsch S, Wagner U, Anderson. 1994. Changes in composition of soil polysaccharides and aggregate stability after carbon amendments to different textured soils. Appl Soil Ecol 1:145-54.
Schmidt MWI, Noack AG. 2000. Black carbon in soils and sediments: analysis, distribution, implications, and current challenges. Global Biogeochem Cycles 14:777-93.

Six J, Conant RT, Paul EA, Paustian K. 2002. Stabilization mechanisms of soil organic matter: Implications for C-saturation of soils. Plant Soil 241:155-76.

Solomon D, Lehmann J, Kinyangi J, Amelungw W, Lobez I, Pell A, Riha S, Ngoze S, Verchot L, Mbugua D, Skjemstad J, Schäfer T. 2007. Long-term impacts of anthropogenic perturbations on dynamics and speciation of organic carbon in tropical forest and subtropical grassland ecosystems. Global Change Biol 13:511-30.

Spaccini R, Mbagwu JSC, Zena TA, Igwe CA, Piccolo A. 2002. Influence of the addition of organic residues on carbohydrate content and structural stability of some highland soils in Ethiopia. Soil Use Manag 18:404-11.

Steiner C, Teixeira WG, Lehmann J, Nehls T, de Macêdo JLV, Blum WEH, Zech W. 2007. Long term effects of manure, charcoal and mineral fertilization on crop production and fertility on a highly weathered Central Amazonian upland soil. Plant Soil 291:275-90.

Tilman D, Fargione J, Wolff B, D'Antonio C, Dobson A, Howarth R, Schindler D, Schlesinger WH, Simberloff D, Swackhamer D. 2001. Forecasting agriculturally driven global environmental change. Science 292:281-4.

Tilman D, Cassman KG, Matson PA, Naylor R, Polasky S. 2002. Agricultural sustainability and intensive production practices. Nature 418:671-7.

Tittonell P, Zingore S, van Wijk MT, Corbeels M, Giller KE. 2007. Nutrient use efficiencies and crop responses to $\mathrm{N}, \mathrm{P}$ and manure applications in Zimbabwean soils: Exploring management strategies across soil fertility gradients. Field Crops Res 100:348-68.

Vitousek PM, Mooney HA, Lubchenco J, Melillo JM. 1997. Human domination of earth's ecosystems. Science 277: 494-9.

Wallace JS. 1996. The water balance of mixed tree-crop systems. In: Ong CK, Huxley P, Eds. Tree-crop interactions, a physiological approach. Wallingford, UK: CAB International. pp 73-158.

Wang JJ, Harrell DH, Henderson RE, Bell PE. 2004. Comparison of soil-test extractants for phosphorus, potassium, calcium, magnesium, sodium, zinc, copper, manganese, and iron in Louisiana soils. Commun Soil Sci Plant Anal 35:145-60.

Warnock DD, Lehmann J, Kuyper TW, Rillig MC. 2007. Mycorrhizal responses to biochar in soil - concepts and mechanisms. Plant Soil 300:9-20.

Yamato M, Okimori Y, Wibowo IF, Anshori S, Ogawa M. 2006. Effects of the application of charred bark of Acacia mangium on the yield of maize, cowpea and peanut, and soil chemical properties in South Sumatra, Indonesia. Soil Sci Plant Nutr 52:489-95. 